\title{
Ethics and College Sports: Ethics, Sports, and the University
}

By Peter A. French. Published 2004 by Rowman and Littlefield Publishers, Lanham, Maryland. (193 pp.) ISBN: 0-7425-1273-8

Reviewed by Randy Feezell, Department of Philosophy, Creighton University, Omaha, Nebraska.

A book on ethics and college sports might examine any number of issues associated with intercollegiate athletics, including various kinds of cheating (for example, in recruiting, sustaining eligibility by doctoring transcripts, in coursework, on the playing field, etc.), the prevalence of aggression in contemporary sports, the use of performance-enhancing drugs, or the apparent decline of sportsmanship in the conduct of players, coaches, and fans. All of these topics deserve serious attention. Yet for those of us who have worked in universities or played and coached in college sports, especially in the context of big-time intercollegiate athletics, the deepest issue, the most puzzling and troubling issue, isn't any particular aspect of our scholastic games. It's the very existence of college sports that occasions our wrinkled brows, intermittent resentments, skeptical interrogations, and even outraged responses. Why do we invest so many resources to sustain athletic programs in universities and colleges? Given the highly publicized problems and the financial investments required, especially at the highest levels of college sports, what could justify their status on campuses across America? This is the central issue in Peter French's excellent critical examination of what he calls "elite sports" and "prestige sports," primarily football, men's basketball, and perhaps women's basketball. He says: "...I am far more concerned with what I take to be basic issues regarding the role of intercollegiate athletics within the mission of the American university. Can the very existence in the academy of intercollegiate athletics, especially the high-profile or 'big-time' prestige or elite sports of football and basketball, be justified" (p.1)? Put more succinctly, "...the issue is, "What are these programs doing on our campuses"” (p.3)?

When such a fundamental question is raised, I think there is a striking disconnect between those within universities, whose careers and even identities are intimately connected with the educational mission of institutions of higher learning, and a general public whose primary involvements with universities may include only distant memories or the outcome of current and past sporting events, rather than the pursuit of knowledge, the nurturing of young scholars, or contributing to the development of a liberally educated citizen. Many academics have their favorite anecdotes about ill-prepared "student-athletes" in their classes and subtle or not too subtle pressures that call for accommodation or the compromise of academic standards when it comes to teaching such students. French describes his experience as a graduate assistant at a football powerhouse. He had the audacity to give a failing midterm grade in an elementary logic class to a star lineman who was 
registered for the course but never attended the class sessions. After a phone call from the football coach indicating that the grade was unacceptable, along with admonishments for the lowly G. A., ("Who did I think I was?"), the matter was handled by the department chair. The lineman played in all games throughout his years of eligibility and he went on to have a splendid career in the NFL (p. 46-47).

I could fill this review with similar anecdotes from my own experiences, occurrences that are neither apparent nor troubling for the Fan, Sports Talk Guy, or Booster. I attended a big-time sports university on a full athletic scholarship, and I was later a graduate assistant there. I was once called upon to give some very special all-day emergency tutorial support at the end of finals week for a freshman football player who didn't attend the last half of the course and had already gone home, having given up his hope of passing introduction to philosophy_and remaining eligible. This confused young man had been the central character in a transcript scandal (as I recall) publicized in a major Sports Illustrated exposé. He had the potential to be a great option quarterback so we had to keep him eligible. Later, as a professor and one-time Athletic Board Chair at a Division I institution, through the years I have had access to certain kinds of troubling facts and even "dirt" associated with our athletic program. Our fans and supporters are largely unaware of such matters, although some will recall that we sent one of our basketball players to a special elementary school in Chicago to improve his reading skills after he left our university. (That is, perhaps, a low blow. By and large, I think the integrity of our athletic program stacks up rather well in relation to others in Division I Athletics; however, compromises, both academic and financial, may be inevitable in "elite sports.") The central point is this: while the justification issue may seem unrealistic or irrelevant to the general public, it is vital for those in higher education, and I can think of no better book than French's to help both academics and the public think about key questions related to the realities of intercollegiate athletics.

Given the centrality of the question of why these programs are on campus, the way that French structures the discussion is clear and compelling. "My strategy is that if the athletic programs are to be justified, they must be able to identify themselves with a generally agreed-on mission or missions of their universities" (p.2). In Chapter 1, "The Mission of the University and the Role of Intercollegiate Athletics," he provides a brief account of the mission statements of some universities with highly successful programs in the elite sports: the University of Miami, the University of Michigan, Arizona State University, the University of Tennessee, the University of Texas, and the University of North Carolina. The complete mission statements, as well as each university's athletic department mission statement, are in an appendix. (The book includes over sixty pages of useful appendices, including mission statements, NCAA statements on sportsmanship and banned drugs, and a summary of NCAA regulations for Division I.) The mission statements contain predictable references to teaching, research, and creative activities, yet the goals of such large institutions are multi-faceted and complex, and "all these mission statements...stress service to the local, state, and national communities as a dominant theme" (p. 5). French's argument, which insists that "the articulated mission(s) of universities will be the ultimate measuring stick against which a justification should be evaluated" (p. 6), leads to an unsurprising (but finely articulated) conclusion about the failure of standard justifications for high-level intercollegiate athletics, a more surprising but interesting conclusion about what does justify these programs, 
and some provocative suggestions about the policy consequences for athletes if we accept such a justification.

In my view, there are three standard arguments that attempt to justify college sports. I call these the Education Argument, the Economic Argument, and the Community-Building Argument. Versions of these arguments have been examined in recent books. French's study effectively builds on and extends the work of James L. Shulman and William G. Bowen, James Duderstadt, Murray Sperber, Robert Simon, and others. Briefly put, the defenders of intercollegiate sports often insist that these programs are compatible with or even enhance the educational mission of universities and colleges by instilling important character traits that are transferable to life beyond athletics; provide valuable financial support for the university, including its academic mission; and reinforce "school spirit" and identification with the university, a connectedness that enhances life on campus and encourages financial contributions later. Two of the chapters of French's book deal directly with these arguments: Chapter 3, "The Character Education Myth", and Chapter 5, "The Funding Myth". Chapter 2, "The Amateur Myth", begins the examination of the justification of intercollegiate athletics, because we "must take into consideration such things as the rules and conditions of eligibility that the NCAA imposes on those participating in intercollegiate athletic programs as well as the costs of running major intercollegiate athletic programs" (p. 7). Chapter 4, "The Gender Equity Joke", indirectly engages the central arguments by describing the clash between Title IX requirements involving proportionality and the effective accommodation of athletic interests, and the enormous resources spent on big-time football. Chapter 6, "The Entertainment Reality", returns the discussion to the service mission of these large universities and argues that the only way to make sense of the realities surrounding elite college sports is to admit that they provide entertainment to the community, an important and justifying reason for their existence.

In my judgment, the chapters on amateurism and gender equity are not as crucial to the overall argument, but they are interesting and valuable nevertheless. According to French, the NCAA's concept of amateurism is a direct descendent of an outmoded and morally pernicious $19^{\text {th }}$ century British ideal that effectively excluded the working class from participating with "gentleman amateurs" in sporting contests and was used to perpetuate a "morally indefensible social system" (p. 11). French discusses and rejects the NCAA's eligibility requirements that depend on misguided and confused notions that relate professionalism and competitive equity. He ends by examining a motivational concept of amateurism (participating for the sake of the internal goods of a practice) but recognizes that such an account, while appealing, would be difficult to apply (p. 26-27). The major problem, however, is that "the very conception of amateurism that defines it in terms of the acquisition of the internal goods of the sport will prove of no value whatever to the justification of intercollegiate athletics on the university campus" (p. 27). In the chapter on gender equity, French discusses familiar work by Robert Simon, Jan Boxill, and Leslie Francis, and concludes that as long as universities have football, issues of distributive justice are inevitable. An athletic director is quoted as saying, "Gender equity is a joke;" "they'll never achieve proportionality" because "they'll never be able to reign in football and men's basketball" (p.76).

In terms of the standard arguments for elite sports, the heart of the book is the discussion of the "character education myth" and the "funding myth". I have 
never read a more effective, though relatively brief critical discussion (some might say-demolition) of the argument that attempts to justify big-time intercollegiate athletics by claiming that athletics is a "training ground for good character" (p. 32), teaches "the lessons of life that produce men and women of good moral character" (p. 33), or "that participation in athletics supplements the educational process of the students by giving them experiences on the playing fields that ingrain in them important moral virtues that they will evidence in the community after they graduate" (p. 33). (This is, of course, a version of the old character-building argument.) Along the way, French makes a number of important points. In practice, athletes' experiences look more like basic training than education. "What virtues, other than the dubious one of obedience to authority, are the athletes learning" (p. 44)? Autonomy? No. "Of all the students on campus, none are afforded less freedom to explore their moral development and autonomy than those participating in intercollegiate athletics. Their lives are the most regulated and supervised on campus" (p.44).

French claims that few coaches, whose job is to win, seem to take on the role of moral educator (p. 46). The argument is "further eroded, if not trashed altogether" when "those programs are racked with scandals that have been instigated and perpetuated by coaches and athletic directors" (p. 46). Scandals involving plagiarism (for example, tutors writing papers for athletes) constitute a "direct attack on the values of the academy" (p. 47), especially intellectual honesty. A more philosophically interesting point involves reference to the development of particular virtues. Merely listing certain traits that might be developed in sports participation overlooks the important Aristotelian point that the virtues must be organized in certain ways and directed toward certain ends in order to contribute to a good human life. (The villain may be characterized by perseverance and courage.) And, this point leads directly to the conclusion produced by empirical research, "that there is virtually no translatability of morally acceptable virtues and values from the playing field to ordinary life" (p. 52). In fact, research indicates that athletes tend to bracket the norms of competitive athletic contests from the norms of ordinary life (p. 53), "resulting in moral callousness both on and off the playing field" (p. 56). French says: "Perhaps the overarching conclusion of the empirical studies is that all this business about the inherent virtues of athletic participation is a myth concocted by the athletic enthusiasts to justify the inclusion of athletics in educational institutions" (p. 55). Finally, even if the character education argument has some plausibility for some athletes (how many?), "how could you endorse the expenditure of the millions of dollars required to support intercollegiate sports when so small a percentage of the student body could be expected to receive the purported benefits" (p. 57)?

The chapter on the "funding myth" (The Economic Argument) reiterates what various studies have shown, that there is very little evidence that "intercollegiate athletics provide a significant source of revenue for universities and that this revenue is or can be used to further the primary mission(s) of the university" (p. 79). In fact, financial reports often make use of accounting shenanigans rather than "rigorous accounting principles" (p. 84). (This discussion is informative for those of us, like me, who are accounting challenged.) Also, there's "little evidence to support the frequently made claim that winning sports teams lead to donors making substantial gifts to the university" (p. 85), and there are real questions of distributive justice when the student body as a whole is assessed a fee for funding the athletic program. The community-building argument is also discussed in this 
chapter, as well as the issue of whether athletes are treated as mere means when forced to act as billboards for athletic apparel companies who give substantial sums of money to coaches whose teams wear the company's gear. With regard to the enhancement of identification with the university, French echoes Murray Sperber's biting comments about the negative reactions of faculty members and students to the "privileges enjoyed by athletes" (p. 90). In the end, I agree with French when he wonders about the value of developing a sense of community by "passive participation in athletic events" (p. 88). He says: "Nevertheless, building a sense of community is hardly a reasonable justification for the level of university support that the elite programs demand" (p. 90).

Despite the failure of the traditional arguments and French's repeated claims that universities, athletic departments, and the NCAA are dishonest and hypocritical in perpetuating these myths as persuasive justifications for intercollegiate athletics, the final chapter does attempt to provide the only plausible defense (he claims) that makes any sense when we attend to the realities of elite sports. The business of big-time intercollegiate athletics is about entertainment - and that is all it's really about. "Big-time intercollegiate athletics is big-time entertainment, and it's about time that those in the business of producing it were honest about what they are providing" (p. 104). Unless we accept this, we can't make sense of how elite sports are conducted. "If that primary mission of those programs is denied or masked in the rhetoric of academics or ethics education, nothing makes sense at all" (p. 104). French discusses the NCAA's "selling out to commercialism" (p. 106) and its "hypocrisy with respect to gambling" (p. 109). The most important point, however, is that once we recognize the primary entertainment function of high profile sports, we can relate this function to the public service mission of universities and thereby provide a more honest account of why universities have these programs on campus. It's not about education-it's about entertainment, as Harold Stoke argued in the 1950s, and Robert Atwell has argued more recently. French claims that the "honest and potentially successful defense of intercollegiate athletics, especially including the elite sports, is that they are the way, or at least one way and probably the most visible and successful way, the university responds to its public service obligations in the area of public entertainment" (p. 115). The upshot? We should recognize that athletes in elite sports are entertainers, not students, and that is the condition under which we bring them to campus. Give up the preposterous notion that athletes are students and the unrealistic ideal that they should be held to the same academic standards as normal students. If we recognize the multiple missions of the university, we will acknowledge that athletics belongs to the "entertainment wing of the university" (Robert Atwell) and we will not have to engage in the academic charades required to sustain the eligibility of elite athletes such as University of Arizona basketball player Miles Simon (whose story at Arizona is discussed). We should pay him and relieve him of meeting "arbitrary academic requirements that were of no interest to him and that were not a part of his recruitment to that institution" (p. 117). Provocative conclusion indeed!

I immensely enjoyed reading this book. It's written by a fine philosopher whose arguments are often sophisticated and insightful. I believe it would work well as a text in undergraduate (or graduate) courses in philosophy of sport or selected courses in sport management or sociology of sport. Its central conclusion is one which many will resist, on the grounds that "universities have absolutely no responsibility to 
provide entertainment for the public and programming for the commercial radio and television networks" (p. 119), as James Duderstadt has maintained. Likewise, many will resist the claim, as I have, that we should give up the "dishonest" notion that elite athletes should be treated as normal students and that we should apply the same academic standards and policies to all students. On the other hand, I confess, as French does, that my thinking about big-time intercollegiate athletics has changed and my views are now much closer to French's.

With regard to the standard arguments that attempt to justify intercollegiate athletics, it's important to remember that French's critical discussion is focused relatively narrowly on elite sports in high-level programs. It would be a mistake to conclude that these attempts to justify collegiate athletic programs fail across the board. I believe that the strength of the standard arguments depends upon factual details about the respective institutions and their athletic programs: the size of the institution, the resources committed to athletics, the number of participating athletes, the economic health of the university (especially for smaller tuition-driven institutions), the size of external support for the programs (the number of butts in seats), the approach of particular coaches, and so forth. On the grounds staked out by French, I think he's successful in undermining the traditional arguments and showing that they are myths. It's not as clear, however, that such arguments have no strength in other contexts in which athletes are needed to pay tuition or treated as autonomous students, or where athletics is kept in the perspective of the academic mission of the university and may be a valuable means to enhance community in small institutions. Nevertheless, French's discussion reminds us to ask just how much it is worth, financially, academically, and ethically (given the problems of distributive justice and treating athletes as mere means), to have such programs on campus, especially when smaller-scale programs may adequately perform the functions that are stressed by the various myths. Club sports, anyone? 